\title{
Panulirus argus virus 1 detected in oceanic postlarvae of Caribbean spiny lobster: implications for disease dispersal
}

\author{
Enrique Lozano-Álvarez ${ }^{1, *}$, Patricia Briones-Fourzán ${ }^{1}$, Juan Pablo Huchin-Mian², \\ Iris Segura-García ${ }^{1}$, Juan Pablo Ek-Huchim ${ }^{2}$, Mónica Améndola-Pimenta ${ }^{2}$, \\ Rossanna Rodríguez-Canul ${ }^{2}$ \\ ${ }^{1}$ Universidad Nacional Autónoma de México, Instituto de Ciencias del Mar y Limnología, \\ Unidad Académica de Sistemas Arrecifales, Puerto Morelos, Quintana Roo, 77580 México \\ ${ }^{2}$ Centro de Investigación y de Estudios Avanzados del Instituto Politécnico Nacional-Unidad Mérida, Yucatán, 97310 México
}

\begin{abstract}
Panulirus argus virus 1 (PaV1), a pathogenic virus that specifically attacks Caribbean spiny lobsters Panulirus argus, was recently detected in newly settled postlarvae of $P$. argus. As PaV1 appears not to be vertically transmitted, infected postlarvae likely acquire PaV1 from the water, but whether this can occur in oceanic waters where the planktonic larvae (phyllosomata) metamorphose into nektonic postlarvae remains unknown. Late-stage phyllosomata and postlarvae of $P$. argus were collected at distances of 2 to $100 \mathrm{~km}$ from the Caribbean coast of Mexico in 2 oceanographic cruises. Most postlarvae were caught in the upper meter of water, usually along with masses of floating Sargassum algae. A PaV1-PCR assay was used to test 169 phyllosomata (stages VI-X) and 239 postlarvae. All phyllosomata tested negative, but 2 postlarvae, 1 from each cruise, tested positive for PaV1. These postlarvae were collected at 55 and $48 \mathrm{~km}$ offshore over depths of 850 and $1800 \mathrm{~m}$, respectively, suggesting that postlarvae can acquire PaV1 in offshore waters. We hypothesize that floating Sargassum may be an environmental reservoir for PaV1. The $\mathrm{PaV} 1$ allele $(460 \mathrm{pb})$ found in an infected postlarva was more closely related to PaV1 alleles found in lobsters from Puerto Rico than in lobsters from any other location (including Mexico), suggesting high gene flow and long-distance dispersal of PaV1, consistent with previous studies of high genetic connectivity across the Caribbean.
\end{abstract}

KEY WORDS: PaV1 · Disease connectivity · Panulirus argus $\cdot$ PCR assays · Puerulus · Viral disease · Sargassum

\section{INTRODUCTION}

Panulirus argus virus 1 (PaV1) is a pathogen that specifically attacks Caribbean spiny lobsters Panulirus argus, a major fishing resource throughout the wider Caribbean region. The life cycle of $P$. argus includes a long (5 to $9 \mathrm{mo}$ ) planktonic larval phase that comprises 10 stages ('phyllosomata') followed by metamorphosis into a swimming, non-feeding postlarva ('puerulus') (Goldstein et al. 2008). Metamorphosis occurs in offshore, oceanic waters beyond the shelf break (Phillips \& McWilliam 2009), from where postlarvae actively swim across the continental shelf to settle in coastal shallow habitats of benthic 
marine vegetation. Therefore, larval connectivity between isolated benthic populations is potentially high (Briones-Fourzán et al. 2008, Kough et al. 2013).

PaV1 was first discovered in 1999 in juvenile $P$. argus from the Florida Keys, USA (Shields \& Behringer 2004). Alternate hosts or reservoirs of PaV1 have not been identified (Butler et al. 2008), although marine vegetation has been suggested as a potential reservoir (Briones-Fourzán et al. 2012). PaV1 can be transmitted by contact, but additional modes of transmission may include waterborne (Butler et al. 2008) and the influx of infected larvae from other systems (Dolan et al. 2014). Moss et al. $(2012,2013)$ detected PaV1 in recently settled pueruli and discovered that lobsters from distant Caribbean locations shared viral alleles, suggesting that PaV1 could be dispersed via larval transport. Yet, recent studies in Florida have found no evidence of vertical transmission of PaV1 (D. C. Behringer pers. comm.), suggesting that pueruli acquire PaV1 from the water. Results from a recent modeling approach (Kough et al. 2015) revealed that if $\mathrm{PaV} 1$ is transported by infected postlarvae rather than through water alone, then the results of the model would be more consistent with genetic linkages of PaV1 as reported by Moss et al. (2013).

Whether $P$. argus pueruli acquire PaV1 (1) in nearshore waters while seeking settlement habitats, (2) in offshore waters while swimming towards the coast, or even (3) before metamorphosis (i.e. as late-stage phyllosomata) remains unknown, mainly because latestage phyllosomata and oceanic pueruli are so highly diluted in the sea that they are difficult to catch in standard plankton nets (Phillips et al. 2006). During ongoing research into the distribution of larvae of spiny and slipper lobsters over the Mexican Caribbean waters, we collected hundreds of late-stage phyllosomata and nektonic pueruli of $P$. argus in oceanic waters. To examine possibilities (2) and (3), we subjected a subsample of these organisms to PCR assays to test for the presence of DNA of PaV1.

\section{MATERIALS AND METHODS}

\section{Collection of organisms}

Nektonic pueruli and late-stage phyllosomata of Panulirus argus were collected during 2 oceanographic cruises (RV 'Justo Sierra') in autumn (November) of 2012 (cruise 1) and spring
(April) of 2013 (cruise 2), over $30500 \mathrm{~km}^{2}$ of Caribbean waters off the eastern coast of the Yucatan Peninsula, Mexico. Distance of sampling stations to the coast varied from 2 to $100 \mathrm{~km}$ over depths varying from 35 to $2700 \mathrm{~m}$, but most were located beyond the shelf break (Fig. 1). Two samplers were towed simultaneously: a large Tucker mid-water trawl (mouth area: $9 \mathrm{~m}^{2}$; length: $12 \mathrm{~m}$; mesh size: $10 \mathrm{~mm}$ ) that filtered water at depths of 5 to $20 \mathrm{~m}$, and a smaller neuston net (mouth area: $1.5 \mathrm{~m}^{2}$; length: $3 \mathrm{~m}_{i}$ mesh size: $3 \mathrm{~mm}$ ) that filtered water within the upper meter of the ocean. The nets were towed exclusively at night, when late-stage phyllosomata and pueruli ascend towards the surface (Calinski \& Lyons 1983, Phillips et al. 2006), and against the prevailing current at speeds of 1.3 to $1.5 \mathrm{~m}$ $\mathrm{s}^{-1}$ for $35 \mathrm{~min}$ on average. The neuston net (but not the mid-water trawl) routinely collected large masses of floating brown algae Sargassum spp. which were thoroughly examined for phyllosomata and pueruli. All phyllosomata and postlarvae of Achelata were immediately separated from each sample, and those belonging to $P$. argus were staged based on Goldstein et al. (2008). We haphazardly selected 169 phyllosomata (stages VII to X) and 239 pueruli for molecular analyses. Organisms from cruise 1 were preserved in liquid nitrogen. Organisms from cruise 2 were preserved in $80 \%$ ethanol at $-20^{\circ} \mathrm{C}$.

\section{Genetic analyses}

Genomic DNA was extracted and purified from whole individual phyllosomata and from the tail mus-

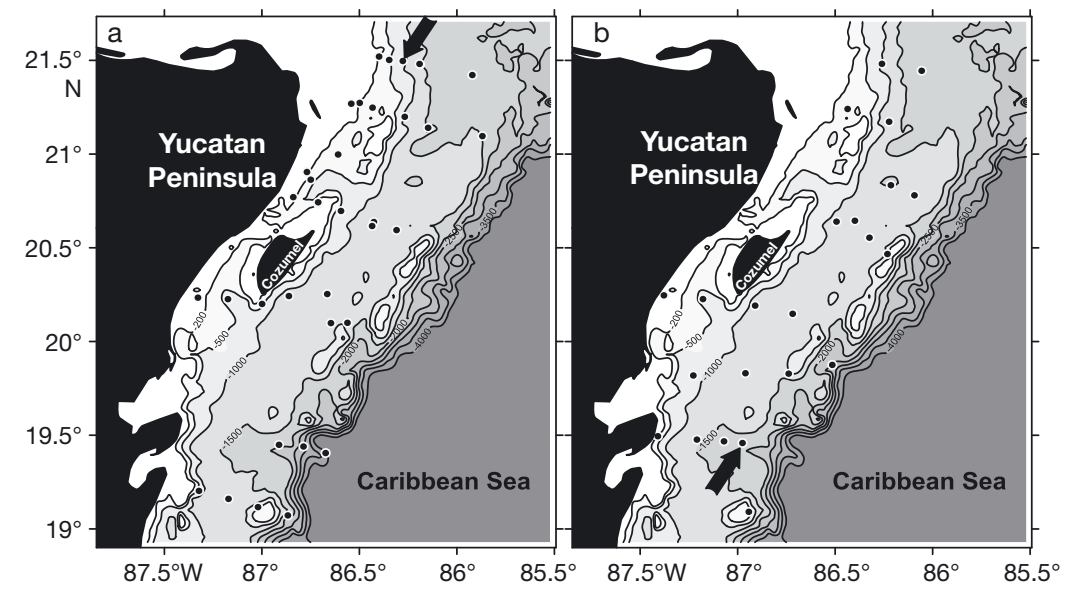

Fig. 1. Sampling stations (large dots) from which planktonic larvae (phyllosomata) and nektonic postlarvae (pueruli) of Caribbean spiny lobster Panulirus argus were tested for the presence of Panulirus argus virus 1 (PaV1) by PCR in (a) November 2012 (cruise 1) and (b) April 2013 (cruise 2). The arrows in panels (a) and (b) show the locations where infected pueruli 1 and 2 were collected, respectively. Depth contours are in meters 
cle of pueruli using either the Wizard ${ }^{\circledR}$ SV Genomic DNA Purification Kit (Promega) or a salt precipitation protocol (Aljanabi \& Martínez 1997) followed by a purification step with a QIAquick purification kit (Qiagen). After extraction, DNA samples were tested with a PaV1-PCR using the primers $45 \mathrm{aF}$ and $543 \mathrm{aR}$ (Montgomery-Fullerton et al. 2007) at a volume of $25 \mu \mathrm{l}$, which included $2.5 \mathrm{mM} \mathrm{MgCl}_{2}, 0.4 \mathrm{mM}$ of each dNTP, $0.33 \mu \mathrm{M}$ of each primer, and 0.75 units of GoTaq® Flexi DNA Polymerase (Promega). Ultrapure water and hemocyte DNA extracted from heavily PaV1-infected lobsters collected from the Puerto Morelos reef lagoon were used as negative and positive controls, respectively (Huchin-Mian et al. 2009). The thermocycle profile consisted of $10 \mathrm{~min}$ of initial denaturation at $94^{\circ} \mathrm{C}_{i}$ followed by 30 cycles of $30 \mathrm{~s}$ at $94^{\circ} \mathrm{C}, 30 \mathrm{~s}$ at $63^{\circ} \mathrm{C}$ and $1 \mathrm{~min}$ at $72^{\circ} \mathrm{C}$; and a final extension of $10 \mathrm{~min}$ at $72^{\circ} \mathrm{C}$. PCR products were electrophoresed in $1.5 \%$ agarose gels stained with ethidium bromide and visualized with UV light. Positive reactions were isolated from the agarose gel using a sterile blade and purified using the Wizard ${ }^{\circledR}$ SV Gel and the PCR Clean-Up System (Promega). PCR products from positive pueruli and the positive controls were sequenced using the automatic sequencer Abi310 (Applied Biosystems) (Sanger et al. 1977). All consensus sequences were submitted to GenBank ${ }^{\mathrm{TM}}$, searching for homologies with the PaV1 database through BLAST (www.ncbi.nlm.nih.gov/Blast.gci).

\section{Phylogenetic tree and haplotype network}

DNA sequences of PaV1 alleles obtained herein and those previously reported by Moss et al. (2013) from adult lobsters (GenBank accession numbers JN786952 to JN786983 and JX987103 to JX987130) and by Montgomery-Fullerton et al. (2007) from juvenile lobsters (EF206313) were used to construct a phylogenetic tree and haplotype network. The phylogenetic tree was obtained through the application of the neighborjoining and BioNJ algorithms to get a matrix of distance by pairs estimated with the maximum composite likelihood method. The topology with the highest log-likelihood value was selected. The analysis was done using MEGA6 software (Tamura et al. 2013).

Network 4.6.1.3 software was used to calculate the minimum spanning network of PaV1 alleles found in infected adult, juvenile, and postlarval $P$. argus (Bandelt et al. 1999), applying a median-joining algorithm with the program default settings. Data related to geographical origins of samples were also incorporated into the analyses.

\section{RESULTS}

All phyllosomata from both cruises tested negative for PaV1, but 2 pueruli, 1 from each cruise, were positive. Most pueruli, including the 2 infected specimens, were collected with the neuston net, i.e. within the first meter of the water column, confirming previous observations that pueruli swim very close to the surface (Calinski \& Lyons 1983). Infected puerulus 1 (i.e. from cruise 1) was collected in the Yucatan strait, $55 \mathrm{~km}$ from the nearest coast (Fig. 1a), over a water depth of $840 \mathrm{~m}$. Infected puerulus 2 (i.e. from cruise 2) was collected $48 \mathrm{~km}$ from the nearest coast (Fig. 1b), over a water depth of $1800 \mathrm{~m}$.

The quality of the PCR product of infected puerulus 1 was low, precluding sequencing, but the amplicon from infected puerulus 2 was successfully sequenced. The consensus sequence found (GenBank accession number KR362560) showed maximum identity with sequences that correspond to PaV1 alleles from 2 adult lobsters from Puerto Rico (JX987104.1 and JX987103.1, Moss et al. 2013; Fig. 2). In contrast, the positive control from Mexico (KR362559) showed maximum identity with original sequences from adults collected in Florida (JX987127.1, see Moss et al. 2013).

The minimum spanning network representing the relationships among PaV1 alleles (Fig. 3) showed that the PaV1 allele found in infected puerulus 2 differed substantially from the positive control and was more related to PaV1 alleles found in $P$. argus lobsters from Puerto Rico than to alleles found in lobsters from any other region, including Mexico. Sequences of unique alleles found in the Bahamas, Dominican Republic, Cuba, and Puerto Rico tended to separate from the other alleles, forming regional 'clusters.' The 2 more frequent alleles were shared by individuals from different geographic regions (in 1 case, the Dominican Republic, Honduras, Florida, and Cuba, and in the other, Florida, Mexico, the Dominican Republic, and Belize), suggesting high gene flow, long-distance dispersal, and high genetic connectivity across the Caribbean.

\section{DISCUSSION}

This is the first report of PaV1 in nektonic pueruli of Panulirus argus collected in oceanic waters. Although infected pueruli represented only a very small proportion of the examined sample, our finding has important implications for disease connectivity, because populations of $P$. argus reproduce through- 


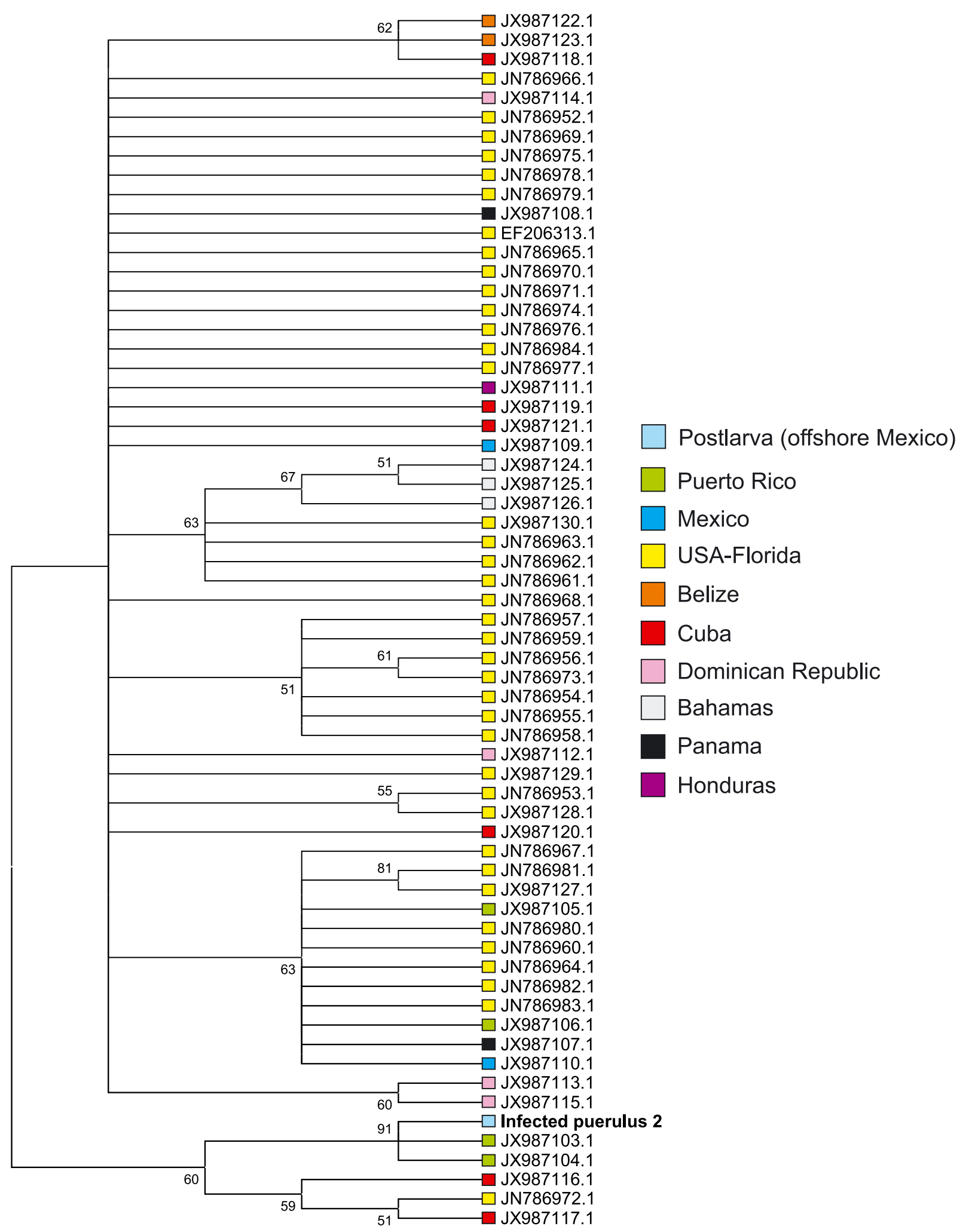

Fig. 2. Molecular phylogenetic tree of Panulirus argus virus 1 (PaV1) with the highest log likelihood (-1227.1619). The percentage of trees in which the associated taxa clustered together is shown next to the branches. The analysis involved 64 nucleotide sequences of PaV1, including the sequence obtained from infected puerulus 2 ('postlarva, offshore Mexico') caught during cruise 2 (April 2013). In total, the final dataset included 409 positions (see Montgomery-Fullerton et al. 2007, Moss et al. 2012, 2013) 


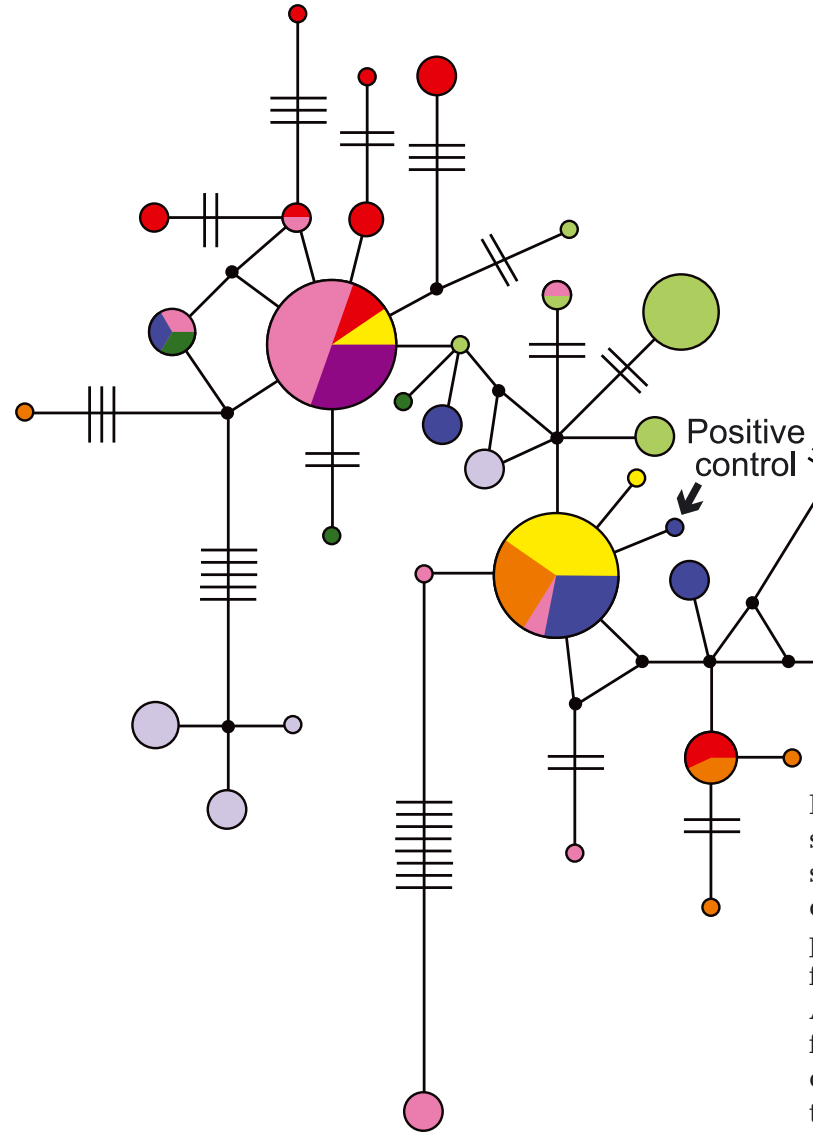

out most of the year and hence there are potentially millions of pueruli in Caribbean waters at any given time. Consistent with a lack of evidence for vertical transmission of PaV1, we did not find PaV1 in phyllosomata. This would suggest that the infected postlarvae acquired PaV1 in offshore waters, because after metamorphosis, the movement of pueruli is directed shoreward rather than being dispersed at random or by prevailing currents (Phillips et al. 2006).

Although there is limited information on how long PaV1 virions can stay infective outside the hosts in natural seawater (Kough et al. 2015), some viral diseases in marine systems have undergone unusually rapid propagation, suggesting a lack of barriers to dispersal in some parts of the ocean and the potential for long-term survival outside their hosts (McCallum et al. 2003). Marine aggregates, onto which viruses may adsorb, can protect viruses from various sources of inactivation and provide them with a means for horizontal transport, potentially resulting in increased infection of organisms such as zooplankton (Weinbauer et al. 2009). Aquatic viruses can also accumulate in submerged macrophytes (Small \& Pagenkopp 2011, Sweet et al. 2013), wherein the

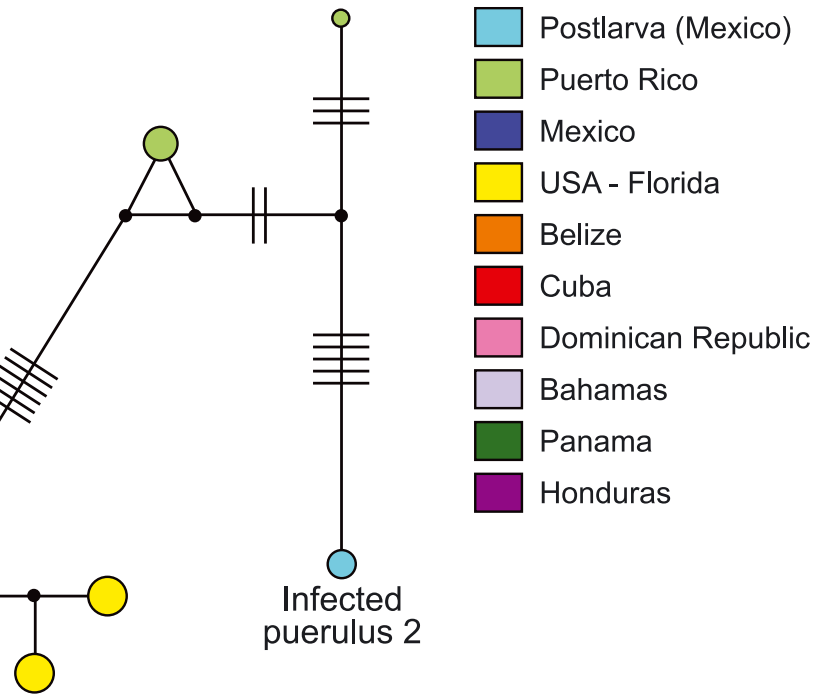

Fig. 3. Minimum spanning network showing associations between sequences of Panulirus argus virus 1 (PaV1). Each circle represents a unique allele. Circle sizes are proportional to the allele overall frequency, and each color corresponds to 1 original sampling region. The circles representing the $\mathrm{PaV} 1$ sequence from infected puerulus 2 caught during cruise 2 ('postlarva, Mexico'; April 2013) and from the positive control (infected benthic juvenile from Puerto Morelos, Mexico) are indicated. Each branch between circles corresponds to a single mutational step, and 2 or more mutational steps are indicated by small transverse lines. Black dots are the median vectors calculated by the program

shade may prolong their viability (Hernández et al. 2005), as has been suggested for PaV1 in benthic habitats (Briones-Fourzán et al. 2012). Interestingly, our neuston net routinely caught large masses of the holopelagic brown algae Sargassum spp., which had to be painstakingly scrutinized for pueruli and phyllosomata. Floating mats of Sargassum constitute the most salient features in surface waters of the tropical Western Atlantic (Gower \& King 2011). Due to Langmuir circulations, these mats accumulate with other floating material (e.g. marine aggregates, plankton) in streaks within the upper meter of the ocean (Barstow 1983), precisely where pueruli swim at night. The confluence of phyllosomata and pueruli with floating Sargassum in plankton samples was previously remarked upon by Gurney (1942) and Sims \& Ingle (1966). Therefore, it is possible that floating Sargassum and/or marine aggregates may provide protection and a means of transport for PaV1, increasing the probability of host-pathogen contact in offshore waters.

Our analyses showed that PaV1 from infected puerulus 2 shared greater homology with PaV1 sequences obtained from lobsters from Puerto Rico 
than with those from Mexico (including the infected lobster used as a positive control) and Florida, suggesting high gene flow and long-distance dispersal (Moss et al. 2013) and providing evidence that postlarvae can act as a vector for PaV1 dispersal across the wider Caribbean region, as recently modeled by Kough et al. (2015). Whether postlarvae infected offshore act as asymptomatic carriers of PaV1 into the settlement habitats, as do shrimp postlarvae infected with white spot syndrome virus (Thakur et al. 2002), or develop the disease after molting into benthic juveniles warrants further evaluation.

Acknowledgements. We thank F. Negrete-Soto and C. Barradas-Ortiz for their invaluable technical support, and Capt. L. Ríos-Mora and the crew of the RV 'Justo Sierra,' as well as E. Escalante-Mancera, R. Martínez-Calderón (who also jointly produced Fig. 1), R. Muñoz de Cote, R. Candia-Zulbarán, A. Espinosa-Magaña, N. Herrera-Salvatierra, and M. Ortiz-Matamoros for assisting in the collection of samples. L. Suescún-Bolívar helped with molecular analyses. This study was funded by Universidad Nacional Autónoma de México and Consejo Nacional de Ciencia y Tecnología, México (Project No. 101200).

\section{LITERATURE CITED}

- Aljanabi SM, Martínez I (1997) Universal and rapid saltextraction of high quality genomic DNA for PCR-based techniques. Nucleic Acids Res 25:4692-4693

Bandelt HJ, Forster P, Röhl A (1999) Median-joining networks for inferring intraspecific phylogenies. Mol Biol Evol 16:37-48

Barstow SF (1983) The ecology of Langmuir circulation: a review. Mar Environ Res 9:211-236

Briones-Fourzán P, Candela J, Lozano-Álvarez E (2008) Postlarval settlement of the spiny lobster Panulirus argus along the Mexican Caribbean coast: patterns, influence of physical factors, and possible sources of origin. Limnol Oceanogr 53:970-985

Briones-Fourzán P, Candia-Zulbarán RI, Negrete-Soto F, Barradas-Ortiz C, Huchin-Mian JP, Lozano-Álvarez E (2012) Influence of local habitat features on disease avoidance by Caribbean spiny lobsters in a casitaenhanced bay. Dis Aquat Org 100:135-148

Butler MJ, Behringer DC, Shields JD (2008) Transmission of Panulirus argus virus $1(\mathrm{PaV} 1)$ and its effect on the survival of juvenile Caribbean spiny lobster. Dis Aquat Org 79:173-182

> Calinski MD, Lyons WG (1983) Swimming behavior of the puerulus of the spiny lobster Panulirus argus (Latreille, 1804) (Crustacea: Palinuridae). J Crustac Biol 3:329-335

> Dolan TW III, Butler MJ IV, Shields JD (2014) Host behavior alters spiny lobster-viral disease dynamics: a simulation study. Ecology 95:2346-2361

Goldstein JS, Matsuda H, Takenouchi T, Butler MJ IV (2008) A description of the complete development of larval Caribbean spiny lobster Panulirus argus (Latreille, 1804) in culture. J Crustac Biol 28:306-327

Gower JFR, King SA (2011) Distribution of floating Sargassum in the Gulf of Mexico and the Atlantic Ocean mapped using MERIS. Int J Remote Sens 32:1917-1929
Gurney R (1942) Larvae of decapod Crustacea. The Ray Society, London

Hernández A, Marina CF, Valle J, Williams T (2005) Persistence of invertebrate iridescent virus 6 in tropical artificial aquatic environments. Arch Virol 150:2357-2363

Huchin-Mian JP, Briones-Fourzán P, Simá-Álvarez R, CruzQuintana Y and others (2009) Detection of Panulirus argus Virus 1 (PaV1) in exported frozen tails of subadultadult Caribbean spiny lobsters Panulirus argus. Dis Aquat Org 86:159-162

Kough AS, Paris CB, Butler MJ IV (2013) Larval connectivity and the international management of fisheries. PLoS ONE 8:e64970

Kough AS, Paris CB, Behringer DC, Butler MJ IV (2015) Modelling the spread and connectivity of waterborne marine pathogens: the case of PaV1 in the Caribbean. ICES J Mar Sci 72(Suppl 1):i139-i146

> McCallum HI, Harvell CD, Dobson AP (2003) Rates of spread of marine pathogens. Ecol Lett 6:1062-1067

> Montgomery-Fullerton MM, Cooper RA, Kauffman KM, Shields JD, Ratzlaff RE (2007) Detection of Panulirus argus Virus 1 in Caribbean spiny lobsters. Dis Aquat Org 76:1-6

Moss J, Butler MJ IV, Behringer DC, Shields JD (2012) Genetic diversity of the Caribbean spiny lobster virus, Panulirus argus virus 1 (PaV1), and the discovery of PaV1 in lobster postlarvae. Aquat Biol 14:223-232

> Moss J, Behringer DC, Shields JD, Baeza A and others (2013) Distribution, prevalence, and genetic analysis of Panulirus argus virus 1 (PaV1) from the Caribbean Sea. Dis Aquat Org 104:129-140

Phillips BF, McWilliam PS (2009) Spiny lobster development: Where does successful metamorphosis to the puerulus occur?: a review. Rev Fish Biol Fish 19:193-215

Phillips BF, Booth JD, Cobb JS, Jeffs AG, McWilliam PS (2006) Larval and postlarval ecology. In: Phillips BF (ed) Lobsters: biology, management, aquaculture and fisheries. Wiley-Blackwell, Oxford, p 231-262

Sanger F, Nicklen S, Coulson AR (1977) DNA sequencing with chain terminating inhibitors. Proc Natl Acad Sci USA 74:5463-5467

Shields JD, Behringer DC Jr (2004) A new pathogenic virus in the Caribbean spiny lobster Panulirus argus from the Florida Keys. Dis Aquat Org 59:109-118

Sims HW Jr, Ingle RM (1966) Caribbean recruitment of Florida's spiny lobster population. Q J Fla Acad Sci 29: 207-241

> Small HJ, Pagenkopp KM (2011) Reservoirs and alternate hosts for pathogens of commercially important crustaceans: a review. J Invertebr Pathol 106:153-164

> Sweet MJ, Bythell JC, Nugues MM (2013) Algae as reservoirs for coral pathogens. PLoS ONE 8:e69717

Tamura K, Stecher G, Peterson D, Filipski A, Kumar S (2013) MEGA6: Molecular Evolutionary Genetics Analysis version 6.0. Mol Biol Evol 30:2725-2729

> Thakur PC, Corsin F, Turnbull JF, Shankar KM and others (2002) Estimation of prevalence of white spot syndrome virus (WSSV) by polymerase chain reaction in Penaeus monodon postlarvae at time of stocking in shrimp farms of Karnataka, India: a population-based study. Dis Aquat Org 49:235-243

Weinbauer MG, Bettarel Y, Cattaneo R, Luef B and others (2009) Viral ecology of organic and inorganic particles in aquatic systems: avenues for further research. Aquat Microb Ecol 57:321-341 